\title{
Untreated Childhood Giant Cell Glioblastoma
}

National Cancer Institute

\section{Source}

National Cancer Institute. Untreated Childhood Giant Cell Glioblastoma. NCI Thesaurus.

Code C115939.

A finding of giant cell glioblastoma in childhood that has not been treated. 